\title{
Volatile profile and sensory quality of new varieties of Capsicum chinense pepper
}

\author{
Perfil de voláteis e qualidade sensorial de novas variedades de pimentas Capsicum chinense
}

\author{
Deborah dos Santos GARRUTI ${ }^{1 *}$, Nayra de Oliveira Frederico PINTO², Victor Costa Castro ALVES \\ Maria Flávia Azevedo da PENHA², Eric de Castro TOBARUELA ${ }^{3}$ Ídila Maria da Silva ARAÚJO ${ }^{1}$
}

\begin{abstract}
The objective of this study was to compare the sensory quality and the volatile compound profile of new varieties of Capsicum chinense pepper (CNPH 4080 a strain of 'Cumari-do-Pará' and BRS Seriema) with a known commercial variety (Biquinho). Volatiles were isolated from the headspace of fresh fruit by SPME and identified by GC-MS. Pickled peppers were produced for sensory evaluation. Aroma descriptors were evaluated by Check-All-That-Apply (CATA) method, and the frequency data were submitted to Correspondence Analysis. Flavor acceptance was assessed by hedonic scale and analyzed by ANOVA. BRS Seriema showed the richest volatile profile, with 55 identified compounds, and up to $40 \%$ were compounds with sweet aroma notes. CNPH 4080 showed similar volatile profile to that of Biquinho pepper, but it had higher amounts of pepper-like and green-note compounds. The samples did not differ in terms of flavor acceptance, but they showed differences in aroma quality confirming the differences found in the volatile profiles. The $C$. chinense varieties developed by Embrapa proved to be more aromatic than Biquinho variety, and were well accepted by the judges.
\end{abstract}

Keywords: flavor analysis; HS-SPME/GC-MS; check-all-that-apply (CATA).

\section{Resumo}

O objetivo deste estudo foi comparar a qualidade sensorial e o perfil de compostos voláteis de novas variedades de pimenta Capsicum (CNPH 4080, uma linhagem de cumari-do-pará, e BRS Seriema), com uma variedade comercial (Biquinho). Voláteis foram isolados do headspace dos frutos in natura por SPME e identificados por CG-EM. Conservas das pimentas foram produzidas para a análise sensorial. Descritores do aroma foram avaliados pelo método Check-All-That-Apply (CATA) e os dados de frequência submetidos à Análise de Correspondência. A aceitação do sabor das amostras foi analisada por meio de ANOVA. A BRS Seriema apresentou rico perfil de voláteis, com 53 compostos identificados, sendo que cerca de $40 \%$ deles são compostos de aroma doce. A CNPH 4080 apresentou perfil semelhante ao da pimenta Biquinho, porém com compostos de odor de pimenta e notas aromáticas verdes em maiores quantidades. As amostras não diferiram entre si quanto à aceitação do sabor, contudo evidenciaram diferenças na qualidade do aroma, confirmando as diferenças encontradas no perfil de voláteis. As variedades C. chinense desenvolvidas pela Embrapa demonstraram ser mais aromáticas que a variedade Biquinho, sendo que todas as amostras agradaram aos consumidores.

Palavras-chave: análise de aroma; HS-SPME/GC-MS; método CATA.

\section{Introduction}

Peppers have been widely used over the years as preservatives and to add flavor to foods. They are cultivated throughout the world, and China is the largest producer followed by Mexico and Turkey. The popularity of pepper in the U.S. has been increasing over the years and, in 2010, 932,580 MT pepper was produced to meet growing demand (CHINN; SHARMA-SHIVAPPA; COTTER, 2011; FOOD..., 2012).

The genus Capsicum comprises 31 species, of which five are domesticated and the others are classified as semi-domesticated and wild. Capsicum chinense originated in the Americas and, among all domesticated species, is the most widespread in tropical America with great biological diversity (SOUZA; MARTINS; PEREIRA, 2011). Due to its wide adaptation to both tropical and equatorial climates, it is the most produced and consumed species of pepper in Brazil (LANNES et al., 2007).
The great genetic variability of $C$. chinense is particularly evident in the fruits that may have different shapes, colors, sizes, and pungency levels. While most of $C$. chinense peppers usually present extremely strong pungency and aroma (PINO; FUENTES; BARRIOS, 2011), the variety called Biquinho has a strong pepper aroma without the burning sensation. Its characteristic aroma, combined with a sweet flavor and mild pungency, makes Biquinho well appreciated in culinary as a flavoring agent and even as an appetizer.

There is a wide variety of uses and forms of pepper consumption in Brazil. As a result, the Brazilian pepper market is very segmented and diverse; peppers are sold fresh, as sauce, and as new emerging products, namely canned peppers and special jellies (RIBEIRO et al., 2008).

${ }^{1}$ Embrapa Tropical Agroindustry, CEP 60511-110, Fortaleza, CE, Brasil, e-mail: deborah.garruti@embrapa.br

${ }^{2}$ Food Tecnology Department, Federal University of Ceará - UFC, CEP 60020-181, Fortaleza, CE, Brasil

${ }^{3}$ Pharmacy Faculty, Federal University of Ceará - UFC, CEP 60020-181, Fortaleza, CE, Brasil

${ }^{*}$ Corresponding author 
Over the last decades, consumers have become more demanding in terms of experiencing new aromas and flavors; therefore, flavor and pungency are now considered important quality parameters when creating a new pepper variety (EGGINK et al., 2012). Aiming to expand agribusiness pepper, the Brazilian pepper breeding program, coordinated by the Brazilian Agricultural Research Corporation through its National Center of Vegetables Research (Embrapa Vegetables), takes into account not only good agronomic characteristics such as productivity and multiple resistance to diseases, but also characteristics of industrial interest. Therefore, research has been driven by the content of capsaicin (responsible for the pungency) and by the profile of volatile compounds, responsible for the aroma and flavor, in order to obtain strains able to add desirable characteristics to food preparations.

There are very good studies available in the literature on the volatile compounds of several pepper species. Sousa et al. (2006) evaluated the volatile profile of red, yellow, and purple varieties of Brazilian Capsicum chinense sp. peppers. The GC-MS analysis allowed the tentative identification of 34 compounds, among which the most abundant were hexyl ester of pentanoic acid, dimethylcyclohexanols, humulene, and esters of butanoic acid. Pino et al. (2007) and Pino, SauriDuch and Marbot (2006) studied the volatile compounds of Yucatan Habanero chilli pepper (Capsicum chinense Jack. cv. Habanero); the major constituents were E-2-hexenal, hexyl3-methylbutanoate, Z-3-hexenyl-3-methylbutanoate, hexyl pentanoate, 3,3-dimethylcyclohexanol, and hexadecanoic acid. Orange and brown cultivars were considered better in terms of their flavor-relevant chemical composition than the red cultivars.

Characterizing the volatile fractions of three varieties of Brazilian chilli peppers (Capsicum) at two ripening stages of maturity, Bogusz Junior et al. (2012) identified 77 compounds, mostly esters and sesquiterpenes, in the $C$. chinense murupi. The fruit volatile fraction of 8 Capsicum annuum and two Capsicum chinense accessions as well as 6 intra-specific and 2 inter-specific hybrids developed from crossings among them were analyzed by Moreno et al. (2012). Samples of fruit flesh and placenta plus seeds were analyzed separately. Results suggested that there are ample opportunities for improving the aroma of Capsicum peppers by means of hybridization. However, there is a lack of studies on the relationship between volatiles and sensory profiles.

Among the new varieties of Capsicum chinense peppers developed by Embrapa Vegetable, CNPH 4080 and BRS Seriema stand out. CNPH 4080 is a strain of 'Cumari-do-Pará. It has triangular fruits that are $3 \mathrm{~cm}$ long and $1 \mathrm{~cm}$ wide, which turn yellow when mature. It is very aromatic and spicy, with a degree of pungency around a Scoville rating of 50,000 SHU, Scoville heat units, corresponding to level 8 in the heat scale. 'Cumarido-Pará is widely used as a canned product (IBURG, 2005; LINGUANOTTO NETO, 2004). The variety BRS Seriema, developed from the CNPH 3773 genotype belongs to the varietal group popularly known as "goat". In addition to being very aromatic, this cultivar has good uniformity and productivity with small fruits suitable for processing as canned pepper.
The variety Biquinho, with intensely red or orange colored fruits, about $3 \mathrm{~cm}$ in length and $1.5 \mathrm{~cm}$ in width, is widely grown in the Brazilian Southeast region. It was formerly used as an ornamental plant only, but it is currently used in the preparation of sauces and salads. It is considered a bit pungent chili, presenting around Scoville rating of 1,000 SHU, Scoville heat units, corresponding to level 1 in the heat scale (BONTEMPO, 2007; ZANCANARO, 2008).

The aim of this study was to compare the sensory quality and the volatile profile of the new varieties of Capsicum pepper CNPH 4080 and BRS Seriema with a well-known and appreciated variety, Biquinho.

\section{Materials and methods}

The varieties of Capsicum chinense peppers BRS Seriema, $\mathrm{CNPH} 4080$, and Orange Biquinho were obtained from the Active Germplasm Bank of Peppers at Embrapa Vegetables, Brasilia, DF. They were transported by plane in thermo boxes within six hours to Embrapa Tropical Agroindustry, Fortaleza, CE.

The peppers were selected for full physiological maturity and washed. The samples used for chromatographic analyses were kept frozen at $-18^{\circ} \mathrm{C}$, and those used for sensory analyses were preserved in brine. The flow diagram is illustrated in Figure 1. The fruits were sanitizatized with sodium hypochlorite

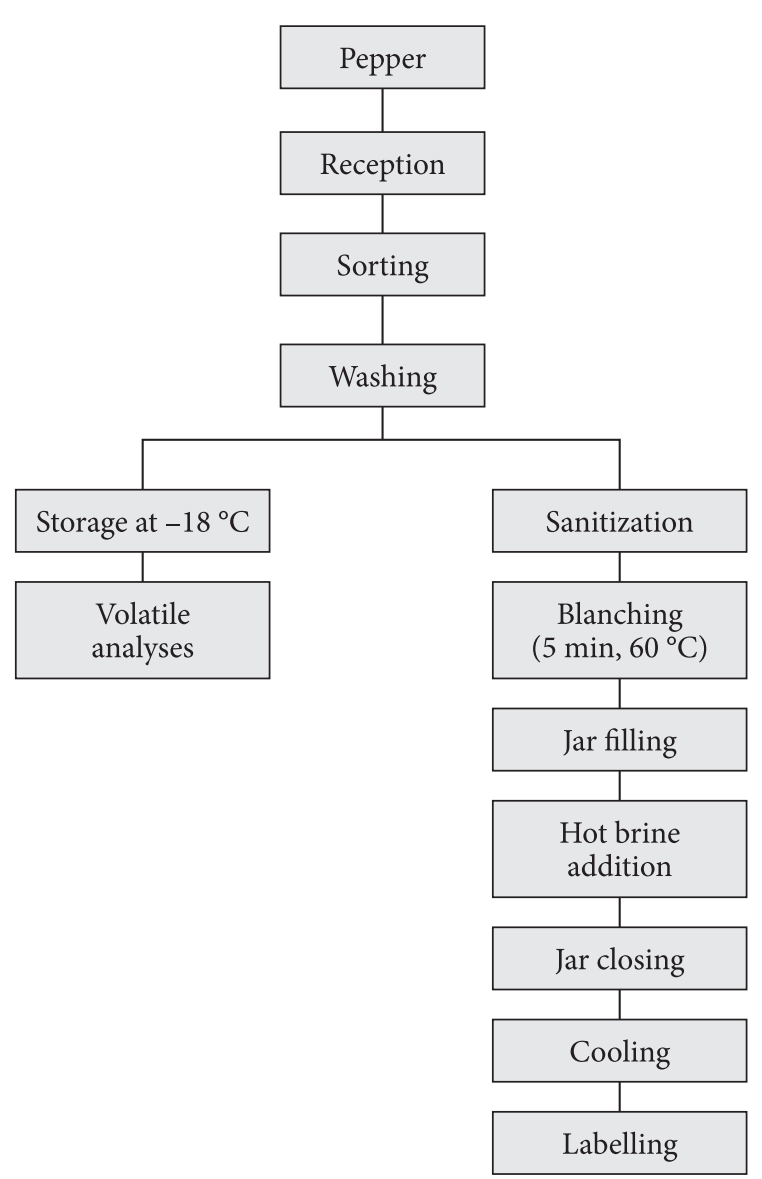

Figure 1. Flow diagram of peppers processing. 
$10 \%$ and bleached $\left(60{ }^{\circ} \mathrm{C}, 5\right.$ minutes $)$. The brine was prepared with white vinegar ( $5 \%$ acidity) and $20 \%$ of marine $\mathrm{NaCl}$. The peppers were placed in sterile glass jars and covered with brine. The jars were closed with metal caps.

\subsection{Volatile analyses}

\section{HS-SPME procedure}

The volatiles were extracted by headspace solid phase micro-extraction (HS-SPME) using conditions adapted from Sousa et al. (2006) and Bogusz Junior et al. (2011). Ten grams of unfrozen fruits were placed in a $40 \mathrm{~mL}$ vial with $\mathrm{PTFE} /$ silicone septa without salt addition. DVB/CAR/PDMS 50/30 fibers (Supelco, Bellefonte, CA, USA) were duly conditioned according to the manufacturer's instructions and exposed to the sample's headspace for 60 minutes at $45^{\circ} \mathrm{C}$, without previous equilibration time.

\section{GC-MS analysis and identification}

After extraction, the fiber was placed into the injector port of the gas chromatograph, and the analytes were desorbed in the splitless mode at $200{ }^{\circ} \mathrm{C}$ for 2.0 minutes. After this period, the fiber remained in the injector for 10 minutes for conditioning.

Volatile compounds were separated and identified in a gas chromatograph Shimadzu GC-2010 (Kyoto, Japan) equipped with a mass spectrometer (GC-MS) Shimadzu QP-2010. A DB-5MS column $(J \& W, 30 \mathrm{~m} \times 0.25 \mathrm{~mm}$ id $\times 0.25 \mu \mathrm{m}$ film thickness) was used for the separation. Helium was the carrier gas at constant flow $1.5 \mathrm{~mL} \cdot \mathrm{min}^{-1}$ (column pressure: $13 \mathrm{psi}$ ). The starting oven temperature was $50^{\circ} \mathrm{C}$, following a linear programming up to $120^{\circ} \mathrm{C}$ at a rate of $5^{\circ} \mathrm{C} \cdot \mathrm{min}^{-1}$, and then the temperature was raised to $180^{\circ} \mathrm{C}$ at $2^{\circ} \mathrm{C} \cdot \mathrm{min}^{-1}$.

The compounds were identified using a quadrupole mass detector at an MS ionization voltage of $70 \mathrm{eV}$ and $1 \mathrm{scan} \mathrm{s}^{-1} \mathrm{MS}$ scan range by comparing the mass spectra with those provided by the library of the National Institute of Standards and Technology (NIST, Gaithersburg, MD, USA). The identification was performed by comparing the retention indices (RI) calculated from a homologous series of alkanes (C9-C21) with the order of elution of the compounds for the same chromatographic column, as reported in literature (NATIONAL..., 2012; ACREE; ARN, 2012; PHEROBASE, 2012).

\subsection{Sensory analysis}

Thirty judges with pepper consumption frequency of at least once a week were recruited according to the procedure described by Meilgaard, Civille and Carr (1999) and Stone and Sidel (2004). Before the test, the judges were asked to sign a Statement of Informed Consent and answer a questionnaire about pepper eating habits and frequency of consumption.

All tests were carried out in individual booths under controlled lighting (white, fluorescent) and temperature $\left(24^{\circ} \mathrm{C}\right)$. The booths were equipped with computer terminals for data collection using FIZZ software (version 2.3). Sensory test procedures were approved by the Research Ethics Committee from the Ceara State University, under protocol number 11044529-5.

\section{Flavor acceptance}

Pickled peppers were processed with ricotta cheese (1:20). Five grams of each preparation were given to the panelists in $50 \mathrm{~mL}$ white plastic cups coded with three-digit random numbers; they were placed on a tray with a spoon and disposable napkins. The samples were presented in a monadic and balanced order (MacFIE et al., 1989) in different sessions. Plain milk was served to eliminate the aftertaste and reduce pungency. The judges registered their impression of flavor acceptance on a nine-point hedonic scale ranging from 'like extremely' to 'dislike extremely'. The data were submitted to ANOVA and the Tukey test $(\alpha=0.05)$ for comparison of means using the FIZZ Calculations software (version 2.3).

\section{Aroma descriptors}

Aroma descriptors were assessed by the Check-All-ThatApply (CATA) method. Crushed peppers ( $1 \mathrm{~g})$ were placed in a tulip-shaped glass and covered with a watch glass. The judges were asked to check all perceived odors from a list of pre-chosen terms (Figure 2). The actual list of terms was defined by trained panels in previous olfactometric analyses. The data consisted of the number of judges that rated each term for each sample. Frequently listed descriptors were more relevant than those less frequently listed. Data were analyzed by the multivariate statistical test Correspondence Analysis using the XLSTAT software (Version 1.02).

\section{Results and discussion}

\subsection{Volatile compounds}

A total of 82 compounds were detected in the volatile fraction of the Capsicum chinense peppers studied, from which 64 were identified and reported in Table 1 showing the peak areas and description obtained in an olfactometry study (not published). The main chemical class was esters

\section{ODOR TEST}

Name: Date:

You are receiving a sample of pepper. Please after as slight stirring in a circular motion, open the cup, smell the sample and indicate, among the descriptors below, the odors that you perceive. You may choose as many options as desired and write a new description on the blank line

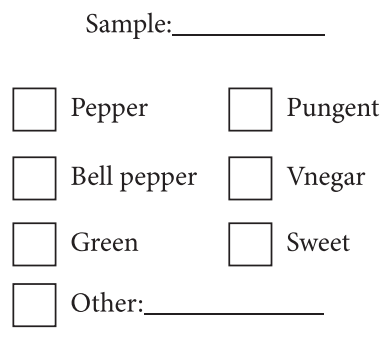

Figure 2. Check-All-That-Apply (CATA) ballot. 
Garruti et al.

Table 1. Volatile compounds identified in the three varieties of Capsicum chinense peppers.

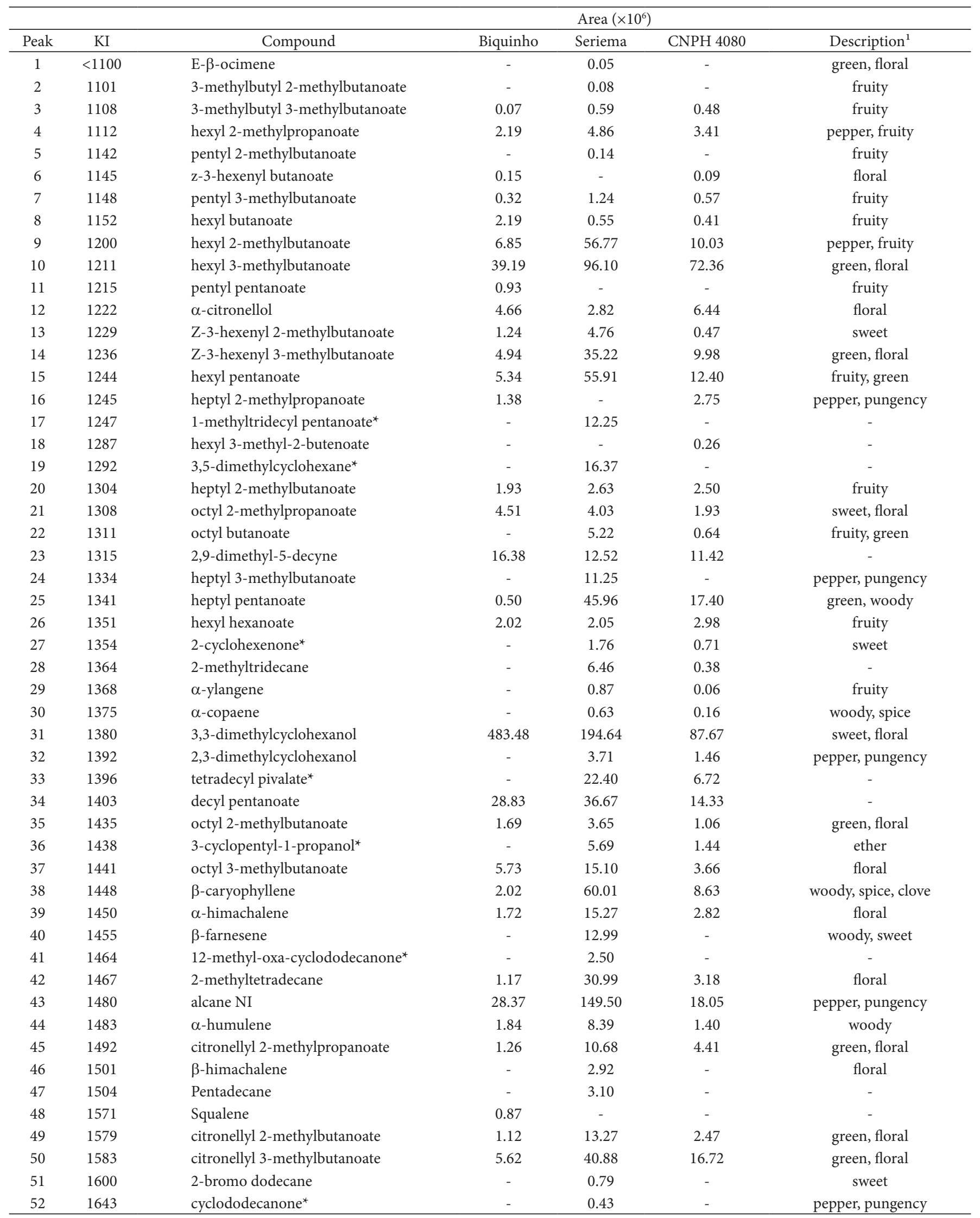

${ }^{1}$ Description according to the literature (ACREE; ARN, 2012; PHEROBASE, 2012). ${ }^{\star}$ Tentatively identified. 
Table 1. Continued...

\begin{tabular}{|c|c|c|c|c|c|c|}
\hline \multirow[b]{2}{*}{ Peak } & \multirow[b]{2}{*}{$\mathrm{KI}$} & & \multicolumn{3}{|c|}{ Area $\left(\times 10^{6}\right)$} & \multirow[b]{2}{*}{ Description $^{1}$} \\
\hline & & Compound & Biquinho & Seriema & CNPH 4080 & \\
\hline 53 & 1646 & 1,1,2-trimethylcycloundecane & - & 0.24 & - & sweet, floral \\
\hline 54 & 1679 & E-2-tetradecenol & - & 0.39 & - & pepper, pungency \\
\hline 55 & 1700 & 2-methylnonadecane & - & 0.27 & - & sweet, floral \\
\hline 56 & 1706 & hexyl decanoate & - & 0.76 & - & - \\
\hline 57 & 1725 & palmitoleic acid & - & 0.95 & 10.38 & - \\
\hline 58 & 1753 & 1-hexadecyne & - & 0.32 & - & sweet, floral \\
\hline 59 & 1866 & exo-isocamphanone ${ }^{*}$ & 4.74 & 3.59 & 4.27 & sweet, floral \\
\hline 60 & 1873 & nonadecyl acetate & - & 0.37 & - & spice \\
\hline 61 & 1896 & 1-tetradecyl acetate & - & - & 1.28 & - \\
\hline 62 & 1937 & methyl palmitate & - & - & 1.32 & - \\
\hline 63 & 1969 & palmitic acid & - & - & 15.18 & - \\
\hline 64 & 2056 & oleyl alcohol & - & - & 6.14 & - \\
\hline
\end{tabular}

${ }^{1}$ Description according to the literature (ACREE; ARN, 2012; PHEROBASE, 2012). ${ }^{\star}$ Tentatively identified.

(51\%), followed by terpenes (17\%), alkanes (13\%), alcohols $(9 \%)$, cetones (7\%), and fatty acids (3\%). The predominance of volatile esters is in agreement with the results found in other varieties of $C$. chinense peppers by several authors, Sousa et al. (2006), PINO et al. (2007), Rodríguez-Burruezo et al. (2010) and Bogusz Junior et al. (2012).

Table 2 shows the number of compounds and the respective total peak area corresponding to each chemical class. From the 32 volatile compounds detected in Biquinho pepper, 22 (69\%) were esters, which corresponded only to $18 \%$ of total area, while two alcohols were responsible to $74 \%$ of the area. In $\mathrm{CNPH}$ pepper esters were also the major class (24 compounds out of 44 ), corresponding to $55 \%$ of compounds and $51 \%$ of chromatogram area. The second major class was alcohols, with $26 \%$ area. BRS Seriema had the richest volatile profile with 55 identified compounds and the highest total peak area counting (1022). Twenty-seven esters comprised $47 \%$ area, while alkanes, alcohols, and terpenes comprised $22 \%, 20 \%$, and $10 \%$, respectively.

The volatile profiles did not show very diverse qualitative patterns; 26 compounds were common to all three samples, and 13 other compounds were common to at least two samples. However, some compounds varied greatly, quantitatively. 3,3-dimethylcyclohexanol, which usually presents sweet and floral odors, was the major compound in all pepper varieties, but it was found in much greater amount in Biquinho pepper. On the other hand, hexyl 2-methylbutanoate, Z-3-hexenyl-2methyl butanoate and hexyl pentanoate, which also has sweet and fruity aroma, were higher in BRS Seriema. The second major compound of Biquinho was hexyl 3-methylbutanoate, characterized by herbal notes. Peaks of the compounds decyl pentanoate, 2,9-dimethyl-5-decyne, and a non-identified alkane also showed relatively high area counting.

CNPH 4080 showed a qualitative volatile profile similar to that of Biquinho, but most compounds were present in higher amounts, such as hexyl 2-methylbutanoate and heptyl 2-methylpropanoate, both with pepper aroma; hexyl 3-methylbutanoate, hexyl pentanoate, heptyl pentanoate, citronellyl 2-methylpropanoate, citronellyl 2-methylbutanoate, and citronellyl 3-methylbutanoate, contributors of green notes. Compounds with sweet aromas were not abundant in this variety.

In BRS-Seriema, high levels of hexyl 3-methylbutanoate (green), hexyl 2-methylbutanoate (fruity, pepper), hexyl pentanoate (fruity), heptyl pentanoate (green), $\beta$ - caryophyllene (woody, spicy), and citronellyl 3-methylbutanoate (green, floral) were found. Its volatile profile had nine terpenoid compounds, from which $\beta$-caryophyllene (woody, spice) and $\alpha$-himachalene (floral) were present in much greater amounts than the others, and $\mathrm{E}$ - $\beta$-ocimene (green, floral), $\beta$-farnesene (sweet) and $\beta$-himachalene (floral) were found only in this variety. Up to $40 \%$ of the volatile compounds had sweet odor notes, $20 \%$ had green and floral notes, and $15 \%$ had pepper aroma. Approximately $45 \%$ of minor compounds also showed sweet aroma.

\subsection{Sensory analysis}

All Capsicum chinense peppers showed good acceptability, reaching mean hedonic rates around 7 which corresponds to "like moderately" in the hedonic scale, with no statistical difference between means $(p>0.05)$ indicating that the three varieties were well accepted by the judges, who showed no preference for one over the others. However, the samples showed differences in the frequency distributions of the hedonic values rated by the judges (Figure 3). Biquinho samples received higher frequency of "liked extremely" (9) and in the indifference category ( $5=$ neither like, nor dislike). Among the new varieties, BRS Seriema showed distribution at a better acceptance region of the hedonic scale, with mode 8 ("like very much", $40 \%$ ), while CNPH 4080 showed mode 7 ("like moderately", 46\%).

Odor analyzes revealed differences in the aroma descriptors confirming the differences in the profile of volatiles. Figure 4 shows the main aroma descriptors used to describe the C. chinense peppers. In the Correspondence Analysis graph, the better dimensional representation of data explains $100 \%$ of the total variance, and the first axis discriminates the varieties BRS 
Garruti et al.

Table 2. Number and area of volatile compounds per chemical class in the three varieties of Capsicum chinense peppers.

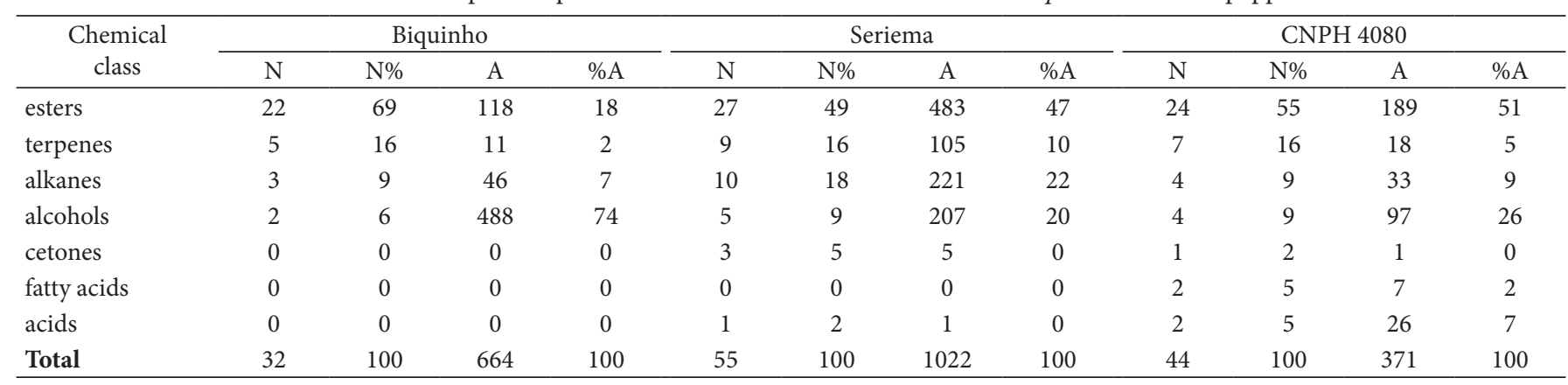

$\mathrm{N}=$ number of compounds; $\mathrm{A}=$ total peak area.

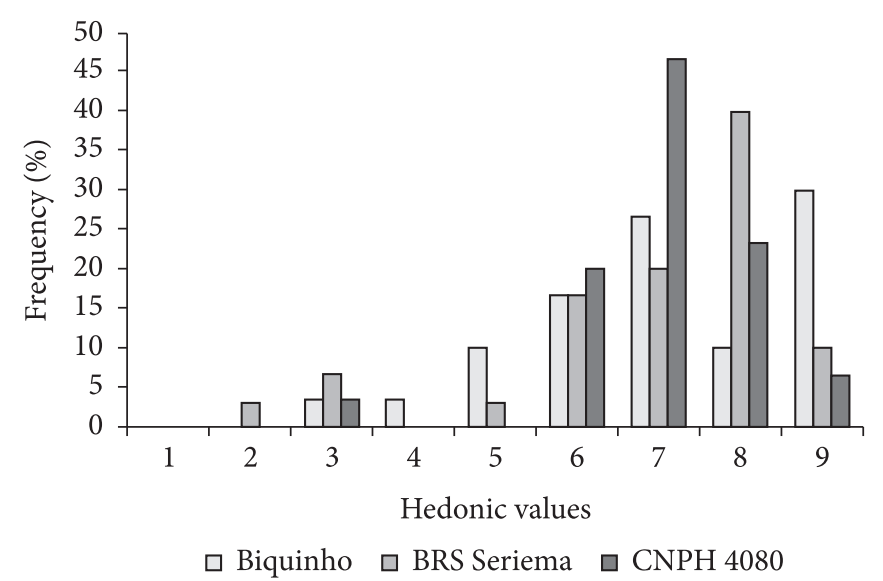

Figure 3. Frequency of hedonic values assigned by consumers for each sample.

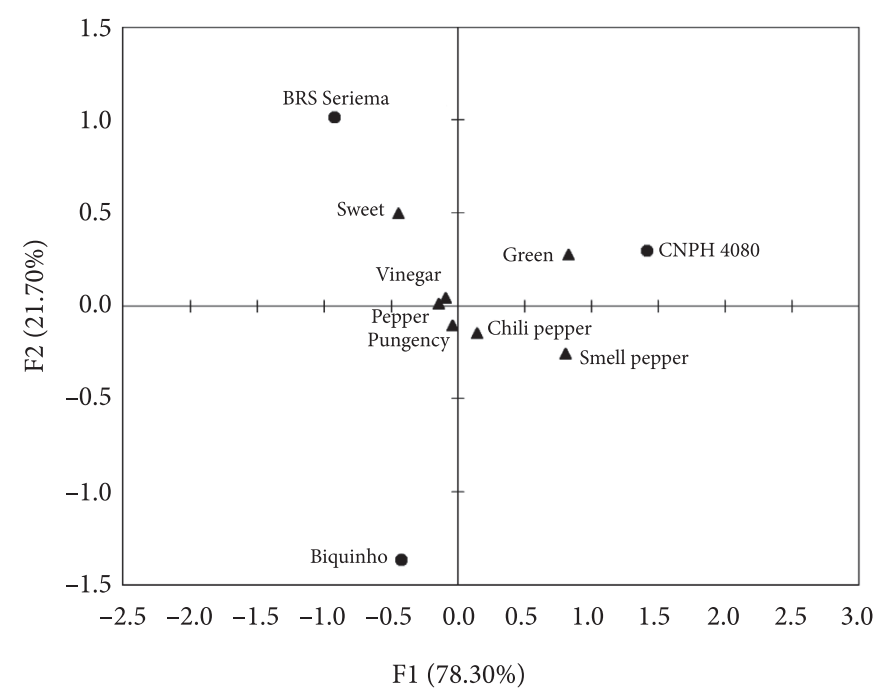

Figure 4. Aroma descriptors of $C$. chinense peppers determined by the CATA method.

Seriema and Biquinho from the CNPH 4080 variety. This axis accounts for $78.30 \%$ of the variance. The second axis represents the odor characterization that discriminates the varieties BRS
Seriema and CNPH 4080 from the Biquinho variety. The fact that all three samples are in different quadrants shows that each one has specific aromatic characteristics.

Analyzing the aroma characteristics in Figure 4, we can see a group of descriptors in the center of the graph, indicating that these descriptors are common to the three pepper varieties, and the differentiation among them is due the most isolated descriptive terms. It can also be observed that BRS Seriema was characterized by a sweet aroma; $\mathrm{CNPH} 4080$ was associated with green (herbal) and pepper aromas, while Biquinho aroma was less intense for most descriptors.

\section{Conclusions}

The three Capsicum chinense peppers did not differ in terms of flavor acceptance means ( $p>0.05)$, but they showed differences in the aroma descriptors confirming the differences in the volatile profile. BRS Seriema was characterized by a sweet aroma, while CNPH 4080 was more associated to green (herbal) and pepper notes. The aroma of Biquinho pepper was less intense for most descriptors. The new varieties developed by Embrapa showed to be more aromatic than the commercial Capsicum variety, with distinc aromas, but all samples were well accepted by the judges.

\section{Acknowledgements}

The authors are grateful for the financial support provided by $\mathrm{CNPq}$ (Conselho Nacional de Desenvolvimento Científico e Tecnológico) and to Embrapa Vegetables for supplying the fruits and for technical assistance.

\section{References}

ACREE, T.; ARN, H. Flavornet And Human Odor Space. Gas chromatography - olfactometry (GCO) of natural products Sponsored by DATU Inc. Cornell University, 2012. Disponível em: <http://www.flavornet.org/flavornet.html>. Acesso em: 19 mar. 2012.

BOGUSZ JUNIOR, S. et al. Optimization of the extraction conditions of the volatile compounds from chili peppers by headspace solid phase micro-extraction. Journal of Chromatography A, v. 1218, n. 21, p. 3345-3350, 2011. PMid:21227437. http://dx.doi.org/10.1016/j. chroma.2010.12.060 
BOGUSZ JUNIOR, S. et al. Analysis of the volatile compounds of Brazilian chilli peppers (Capsicum spp.) at two stages of maturity by solid phase micro-extraction and gas chromatography-mass spectrometry. Food Research International, v. 48, p. 98-107, 2012. http://dx.doi.org/10.1016/j.foodres.2012.02.005

BONTEMPO, M. Pimenta e seus benefícios à saúde. São Paulo: Editora Alaúde, 2007. PMCid:2078254.

CHINN, M. S.; SHARMA-SHIVAPPA, R. R.; COTTER, J. L. Solvent extraction and quantification of capsaicinoids from Capsicum chinense. Food and Bioproducts Processing, v. 89, p. 340-345, 2011. http://dx.doi.org/10.1016/j.fbp.2010.08.003

EGGINK, P. M. et al. A taste of sweet pepper: Volatile and non-volatile chemical composition of fresh sweet pepper (Capsicum annuum) in relation to sensory evaluation of taste. Food Chemistry, v. 132, p. 301-310, 2012. http://dx.doi.org/10.1016/j.foodchem.2011.10.081

FOOD AND AGRICULTURE ORGANIZATION OF THE UNITED NATIONS - FAO. Agricultural Data, 2008. FAOSTAT, Agricultural Production. FAO, 2012. Disponível em: <http://faostat.fao.org/ site/339/default.aspx $>$. Acesso em: 10 jul. 2012.

IBURG, A. Especiarias de A-Z. São Paulo: Lisma, 2005.

LANNES, S. D. et al. Growth and quality of Brazilian accessions of Capsicum chinense fruits. Scientia Horticulturae, v. 112, n. 3, p. 266-270, 2007. http://dx.doi.org/10.1016/j.scienta.2006.12.029

LINGUANOTTO NETO, N. L. Dicionário Gastronômico: Pimentas com suas receitas. São Paulo: Boccato, 2004.

MacFIE, H. J. et al. Designs to balance the effect of order of presenttion and first-order carry-over effects in hall tests. Journal of Sensory Studies, v. 4, p. 129-148, 1989. http://dx.doi.org/10.1111/j.1745459X.1989.tb00463.x

MEILGAARD, M.; CIVILLE, G. V.; CARR, B. T. Sensory evaluation techniques. 3rd ed. New York: CRC, 1999. p. 281. http://dx.doi. org/10.1201/9781439832271

MORENO, E. et al. HS-SPME study of the volatile fraction of Capsicum accessions and hybrids in different parts of the fruit. Scientia Horticulturae, v. 135, p. 87-97, 2012. http://dx.doi.org/10.1016/j. scienta.2011.12.001

NATIONAL INSTITUTE OF STANDARDS AND TECHNOLOGY - NIST. Database Standard Reference
Number 69. NIST, 2012. Disponível em: <http://webbook.nist.gov/ chemistry/>. Access: Mar 19, 2012.

PHEROBASE. Database of Pheromones and Semiochemicals. ElSayed AM, 2012. Disponível em: <http://www.pherobase.com/>. Acesso em: 19 mar. 2012.

PINO, J. et al. Characterization of total capsaicinoids, colour and volatilecompounds of Habanero chilli pepper (Capsicum chinense Jack.)cultivars grown in Yucatan. Food Chemistry, v. 104, p. 16821686, 2007. http://dx.doi.org/10.1016/j.foodchem.2006.12.067

PINO, J.; FUENTES, V.; BARRIOS, O. Volatile constituents of Cachucha peppers (Capsicum chinense Jacq.) grown in Cuba. Food Chemistry, v. 125, p. 860-864, 2011. http://dx.doi.org/10.1016/j. foodchem.2010.08.073

PINO, J.; SAURI, E. D.; MARBOT, R. Changes in volatile compounds of Habanero chile pepper (Capsicum chinense Jacq. cv. Habanero) at two ripening stages. Food Chemistry, v. 94, p. 394-398, 2006. http://dx.doi.org/10.1016/j.foodchem.2004.11.040

RIBEIRO, C. S. C. et al. (Eds.). Pimentas Capsicum. 21. ed. Brasília: Embrapa, 2008. 200 p.

RODRÍGUEZ-BURRUEZO, A. et al. HS-SPME Comparative Analysis of Genotypic Diversity in the Volatile Fraction and AromaContributing Compounds of Capsicum Fruits from the annuumchinense-frutescens Complex. Journal of Agricultural and Food Chemistry, v. 58, p. 4388-4400, 2010. PMid:20199081. http://dx.doi. org/10.1021/jf903931t

SOUSA, E. T. et al. Multivariate optimization and HS-SPME/GC-MS analysis of VOCs in red, yellow and purple varieties of Capsicum chinense sp. Peppers. Microchemical Journal, v. 82, p. 142149, 2006. http://dx.doi.org/10.1016/j.microc.2006.01.017

SOUZA, S. A. M.; MARTINS, K. C.; PEREIRA, T. N. S. Chromosome polymorphism in Capsicum chinense Jacq. Ciência Rural, v. 41, n. 10 , p. $1777-1783,2011$. http://dx.doi.org/10.1590/S010384782011001000017

STONE, H.; SIDEL, J. L. Sensory evaluation practices. 3rd ed. London: Elsevier, 2004. p. 377.

ZANCANARO, R. D. Z. Pimentas: tipos, utilização na culinária e funções no organismo. Brasília: Curso de Especialização em Gastronomia da Saúde, UnB, 2008. PMCid:2719010. 